Randomized Trial

\title{
Evaluation of the Effectiveness of Lumbar Interlaminar Epidural Injections in Managing Chronic Pain of Lumbar Disc Herniation or Radiculitis: A Randomized, Double-Blind, Controlled Trial
}

Laxmaiah Manchikanti, MD', Vijay Singh, $\mathrm{MD}^{2}$, Frank JE Falco, $\mathrm{MD}^{3}$

Kimberly A. Cash, RT', and Vidyasagar Pampati, MSc $^{1}$

From: 'Pain Management Center of Paducah, Paducah, KY; ${ }^{2}$ Pain Diagnostics Associates, Niagara, Wl; and ${ }^{3}$ Mid Atlantic Spine and Pain Specialists, Newark, DE, and Temple University Medical School, Philadelphia, PA

Dr. Manchikanti is Medical Director of the Pain Management Center of Paducah, Paducah, KY, and Associate Clinical Professor of Anesthesiology and Perioperative Medicine, University of Louisville, Louisville, KY.

Dr. Singh is Medical Director, Pain Diagnostics Associates, Niagara, WI. Ms. Cash is a Research Coordinator at the Pain Management Center of Paducah, Paducah, KY.

Dr. Falco is Medical Director of

the Mid Atlantic Spine and Pain Specialists, Newark, DE, and

Clinical Assistant Professor Temple University Medical School Philadelphia, PA.

Mr. Pampati is a Statistician at the Pain Management Center of Paducah, Paducah, KY.

Address correspondence: Laxmaiah Manchikanti, MD 2831 Lone Oak Road

Paducah, Kentucky 42003

E-mail:drlm@thepainmd.com

Disclaimer: There was no external funding in the preparation of this manuscript. Conflict of interest: None.

Manuscript received: 06/18/2010 Accepted for publication: 07/02/2010

Free full manuscript: www.painphysicianjournal.com
Background: The pathophysiology of lumbar radicular pain is the subject of ongoing research, with a reported prevalence of sciatica or radiculitis ranging from $1.2 \%$ to $43 \%$. Among the numerous nonsurgical interventions available, epidural injections are the most commonly performed interventions in the United States in managing chronic low back and lower extremity pain.

Study Design: A randomized, double-blind, controlled trial.

Setting: An interventional pain management practice, a specialty referral center, a private practice setting in the United States.

Objective: To evaluate the effectiveness of lumbar interlaminar epidural injections with local anesthetic, with or without steroids, in managing chronic low back and lower extremity pain secondary to disc herniation or radiculitis in providing effective and long-lasting pain relief.

Methods: Patients were assigned to one of 2 groups with local anesthetic only or with local anesthetic mixed with non-particulate betamethasone.

Randomization was performed by computer-generated random allocations sequence by simple randomization. Seventy patients were included in this analysis.

Outcomes Assessment: Patient outcomes were measured at baseline, 3, 6, and 12 months post-treatment with the Numeric Rating Scale (NRS), the Oswestry Disability Index 2.0 (ODI), employment status, and opioid intake. Decrease of $\geq 50 \%$ of NRS scores and Oswestry scores were considered significant.

Results: Significant pain relief ( $\geq 50 \%$ ) was seen at 12 months in $74 \%$ of patients in Group I and $86 \%$ in Group II, and $69 \%$ and $83 \%$ in ODI scores respectively.

Significant differences were noted in pain relief characteristics at 6 months between Group I and Group II $(P=0.001)$ and functional status improvement was significantly better in Group II at 6 months and 12 months $(P=0.019$ and 0.045$)$. The overall average procedures per year were 4.3 in Group I and 4.2 in Group II with an average total relief per year of $42.2 \pm 10.5$ weeks in Group I and $41.4 \pm 11.0$ weeks in Group II over a period of 52 weeks in the successful group.

Limitations: The study limitations include the lack of a placebo group and the fact that this is a preliminary report of 35 patients in each group.

Conclusion: Overall, 74\% of patients in Group I without steroids and 86\% in Group II with steroids with lumbar disc herniation or radiculitis might benefit from lumbar interlaminar epidural injections.

Key words: Chronic low back pain, lower extremity pain, disc herniation, radiculitis, lumbar interlaminar epidural injections, epidural steroids, local anesthetic

CLINICAL TRIAL: NCT00681447

Pain Physician 2010; 13:343-355 
umbar disc herniation as a source of radicular pain was first described in American medical literature by Mixter and Barr (1) in 1934. Since then, widespread interest in the disc as a source of radicular pain has been established as the most common problem among chronic pain disorders with significant economic, societal, and health impact (24). The pathophysiology of radicular pain assumes not only a mechanical component, but also multiple other factors including inflammation (5-10).

Epidural injections are the most commonly performed interventions in the United States in managing chronic low back pain $(2,11-22)$. Among several approaches available to access the lumbar epidural space, the lumbar interlaminar approach is the most commonly used, the other 2 being the lumbar transforaminal approach and the caudal approach $(2,11,19-25)$.

In general, the interlaminar approach has been and continues to be preferred as its entry can be directed more closely to the assumed site of pathology, requiring less volume than the caudal route. It also is less risky compared to the transforaminal approach, which is considered to be a more specific approach requiring the smallest volume to reach the primary site of pathology. However, the available evidence continues to be controversial, regarding effectiveness, indications, and medical necessity. Evidence is highly variable based on reviews with ratings ranging from indeterminate to moderate in various publications. The majority of the literature on lumbar interlaminar epidurals appears to be negative $(2,11-13,17-22)$. The common theme has been that they may be effective in the short-term in disc herniation and radiculitis. Overall, some systematic reviews $(2,11,19,21,22)$ have concluded in favor of caudal and transforaminal epidural injections in contrast to lumbar interlaminar epidural injections. However, numerous deficiencies have been encountered despite the widespread availability of literature about lumbar interlaminar epidural injections. The deficiencies include study design (fluoroscopy directed versus blind), sample size, assessment, duration of follow-up, and placebo control. In addition, significant issues have been raised concerning bias and inappropriate study inclusion criteria as well as conclusions (12-17,19-33).

The underlying mechanism of action of epidurally administered local anesthetic and steroid injections is not well understood $(2,11,19-22,34-48)$. However, there is emerging evidence that local anesthetics might be as equally effective as steroids in managing low back pain without disc herniation and also pain of facet joint origin $(41,42,49-60)$. It also has been shown that in rats, nerve root infiltration prevented mechanical allodynia with local anesthetic with or without steroids; suggesting that corticosteroids may be unnecessary for nerve root blocks (42).

Regarding proposed theories of similar effectiveness of local anesthetic with or without steroids, no comparative effectiveness research has been conducted with randomized, double-blind, controlled trials in managing lumbar radicular pain syndrome utilizing fluoroscopic visualization for medication delivery. Consequently, this study was undertaken to evaluate the effectiveness of lumbar interlaminar epidural injections with local anesthetic, with or without steroids, in providing relief for chronic, function-limiting low back and lower extremity pain secondary to disc herniation or radiculitis in a randomized, double-blind, controlled evaluation of 120 patients. This is a preliminary report of the one-year follow-up of 70 patients from this study which is scheduled for a 2-year follow-up with 120 patients.

\section{Methods}

A private interventional pain management practice and specialty referral center in the United States was the study's setting. The Consolidated Standards of Reporting Trials (CONSORT) guidelines were followed as was an extension of the CONSORT statement for reporting of randomized trials $(61,62)$. The study protocol was approved by the Institutional Review Board (IRB) and registered with the U.S. Clinical Trial Registry; its assigned number is NCT00681447.

\section{Participants}

Participants were recruited from new patients presenting for interventional pain management.

Patients were assigned to one of 2 groups. Group I patients received lumbar interlaminar injections containing a local anesthetic (lidocaine $0.5 \%, 6 \mathrm{~mL}$ ). In contrast, Group II patients received lumbar interlaminar injections of $0.5 \%$ lidocaine, $5 \mathrm{~mL}$, mixed with one $\mathrm{mL}$ of non-particulate betamethasone.

\section{Interventions}

All patients were provided with the IRB-approved protocol and informed consent, which described in detail all aspects of the study and the withdrawal process. 


\section{Pre-Enrollment Evaluation}

Pre-enrollment evaluation included demographic data; medical and surgical histories and co-existing disease(s); radiologic investigations; physical examination findings; pain rating score using the Numeric Rating Scale (NRS); functional assessment using the Oswestry Index 2.0 (ODI); work status; and opioid intake.

\section{Inclusion and Exclusion Criteria}

Patients chosen for the study had the following characteristics: disc herniation or radiculitis; at least 18 years old; a history of at least 6 months of chronic function-limiting low back and lower extremity pain; competent to understand the study protocol; able to provide voluntary, written, informed consent; and ability to participate in outcome assessments.

Patients were excluded for the following reasons: previous lumbar surgery; radiculitis secondary to spinal stenosis without disc herniation; uncontrollable or unstable opioid use; uncontrolled psychiatric disorders; uncontrolled medical illness, either acute or chronic; any conditions that could interfere with the interpretation of the outcome assessments; pregnant or lactating women; and patients with a history or potential for adverse reaction(s) to local anesthetics or steroid.

\section{Description of Interventions}

One physician, utilizing fluoroscopy, performed each study procedure on a prone patient in a sterile operating room in an ambulatory surgery setting. Appropriate monitoring and intravenous access were provided. As needed, sedation with midazolam and fentanyl were administered. Following sterile preparation, the lumbar interlaminar space was entered using the loss of resistance technique, confirmed by non-ionic contrast. The epidural space was entered at L5/S1, or one space below the disc herniation level. An attempt was made to direct the flow towards the disc herniation side in cases of unilateral pain and bilaterally in cases of bilateral lower extremity pain. After needle placement confirmation, injections were performed: in Group I, 6 $\mathrm{mL}$ of lidocaine hydrochloride $0.5 \%$ preservative free; in Group II, $5 \mathrm{~mL}$ of lidocaine and one $\mathrm{mL}$ of non-particulate betamethasone.

\section{Additional Interventions}

All patients received their assigned treatments. Unblinding occurred if a patient requested it or if an emergency situation arose. Patients requiring additional lumbar epidural injections had them provided based upon the patient's response with deteriorating pain relief below $50 \%$. Non-responsive patients who continued with conservative medical management were followed without additional epidural injections, unless they requested unblinding.

\section{Co-Interventions}

In this study, no specific physical therapy, occupational therapy, bracing, or interventions, other than the assigned study intervention, were offered. All patients continued their previously directed exercise programs, as well as their employment. Regarding medication, most patients were already taking opioids, non-opioid analgesics, and adjuvant analgesics. Based upon an individual patient's medical necessity and improvement or lack thereof, these medications were either discontinued or the dosages increased.

\section{Objectives}

The study was designed to evaluate the effectiveness of lumbar interlaminar epidural injections with or without steroids in managing chronic low back and lower extremity pain secondary to disc herniation or radiculitis in providing effective and long-lasting pain relief and to evaluate the differences between local anesthetic with or without steroids.

\section{Outcomes}

Patient outcomes were measured at baseline, 3, 6 , and 12 months post-treatment. The outcomes measured were pain, using the NRS pain scale (0-10); functional assessment using the ODI (0-50 scale); employment status; and opioid intake in terms of morphine equivalents. On the NRS scale, 0 represents no pain and 10 represents the worst pain imaginable. Thresholds for the minimum clinically important difference for ODI varied from a 4 to 15 point change from a total score of 50 and more recently, higher minimal improvements $(63,64)$. Pain relief and/or reduction of $50 \%$ or more was considered a significant improvement.

Based on the dosage frequency and schedule of the drug, the opioid intake was converted into morphine equivalents (65).

Employability at the time of enrollment was used to determine employment and work status instead of including all patients as being employable. Patients were put into one of the following employment and work status categories: employable, housewife with no desire to work outside the home, retired, over 65 years old. Patients who were unemployed due to pain, em- 
ployed but on sick leave, or laid off, were considered employable.

When a patient received consistent relief with the initial 2 injections lasting at least 3 weeks, the epidurals were deemed successful. All others were deemed failures.

\section{Sample Size}

The sample size was calculated based on significant pain relief. Considering a 0.05 two-sided significance level, a power of $80 \%$, and an allocation ratio of $1: 1$, 55 patients in each group were required (66). Allowing for a $10 \%$ attrition/ non-compliance rate, 60 subjects were required.

Previous studies of interventional techniques identified 50 to 60 patients (participants) as acceptable (50-60,67-69).

\section{Randomization}

From a total of 120 patients, 60 patients were randomly assigned into each group.

\section{Sequence Generation}

Randomization was performed by computergenerated random allocations sequence by simple randomization.

\section{Allocation Concealment}

The operating room nurse assisting with the procedure randomized the patients and prepared the drugs appropriately.

\section{Implementation}

Patients were invited to enroll in the study if they met inclusion criteria. One of the 3 nurses assigned as coordinators of the study enrolled the patients and assigned them to their respective groups.

\section{Blinding (Masking)}

Group assignments were blinded to both the study patients and the medical personnel who administered the interventions. The injectates used for both groups were clear and indistinguishable from each other. Additional blinding precautions included study patients having their procedures performed side-by-side with non-study patients as part of routine treatments. In addition, the physician performing the procedures did not know whether or not study patients were being treated. Further, a statistician not involved with patient care chose the patients for one year follow-up. Blinding was not interrupted since unblinding results were not disclosed to the treating physician, study patients, or any others.

\section{Statistical Methods}

Proportional differences were tested using chisquared statistic. If a value less than 5 was expected, Fisher's exact test was used. Further analysis was done by using t-test to compare the pre- and post-treatment results of average pain scores and ODI measurements at baseline against those at 3, 6, and 12 months. T-test was also used to compare mean scores between the 2 groups.

\section{Intent-to-Treat-Analysis}

An intent-to-treat-analysis was performed. Either the last follow-up data or initial data were utilized in the patients who dropped out of the study. No other data were available.

A sensitivity analysis with changes in the numeric pain scale was performed utilizing the last follow-up score, best case scenario, and worst case scenario if there were no significant differences, the intention-totreat analysis with last follow-up visit was used.

\section{Results}

\section{Participant Flow}

Figure 1 illustrates the participant (patient) flow.

\section{Recruitment}

The recruitment period lasted from January 2008 to February 2010.

\section{Baseline Data}

Table 1 illustrates each group's baseline demographic and clinical characteristics. Significant differences were observed with gender (larger female population than male population in Group I), mean weight with higher weight in Group I compared to Group II, the mode of onset of pain in Group I with a larger proportion of gradual onset, and with higher pain rating score in Group I.

\section{Analysis of Data}

\section{Numbers Analyzed}

As shown in Fig. 1, Group I patients received lumbar interlaminar epidural injections composed of $6 \mathrm{~mL}$ of a local anesthetic ( $0.5 \%$ lidocaine); Group II's injections 


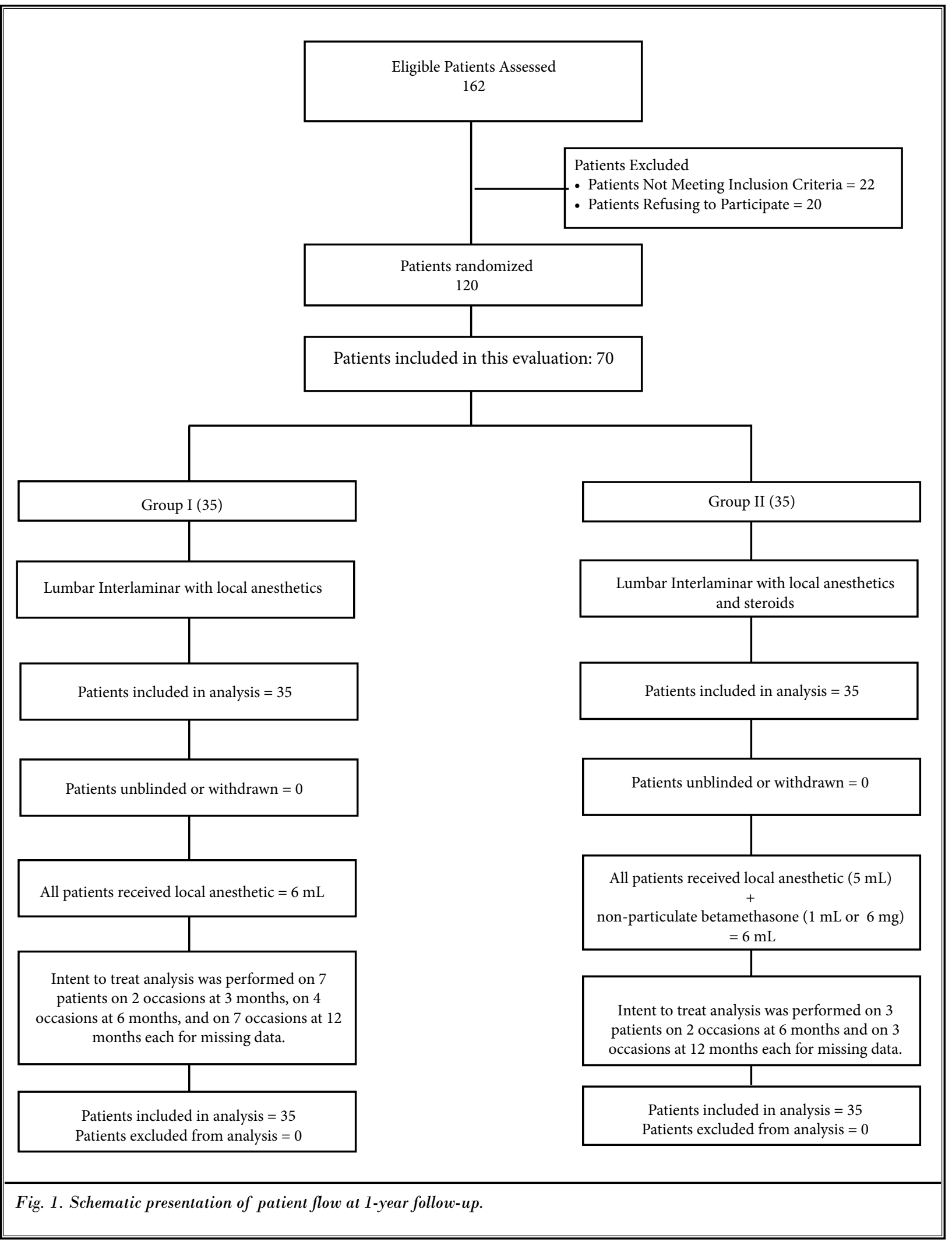


Table 1. Baseline demographic characteristics.

\begin{tabular}{|c|c|c|c|c|}
\hline & & $\begin{array}{c}\text { Group } 1 \\
\text { (35) }\end{array}$ & $\begin{array}{c}\text { Group II } \\
\text { (35) }\end{array}$ & $P$ value \\
\hline \multirow{2}{*}{ Gender } & Male & $20 \%(7)$ & $49 \%(17)$ & \multirow{2}{*}{0.012} \\
\hline & Female & $80 \%(35)$ & $51 \%(18)$ & \\
\hline Age & Mean \pm SD & $42.4 \pm 10.0$ & $41.5 \pm 13.4$ & 0.755 \\
\hline Weight & Mean \pm SD & $211.7 \pm 54.9$ & $179.4 \pm 48.2$ & 0.011 \\
\hline Height & Mean \pm SD & $65.3 \pm 3.6$ & $67.0 \pm 4.3$ & 0.075 \\
\hline Duration of pain (months) & Mean \pm SD & $111.1 \pm 79.8$ & $131.3 \pm 102.7$ & 0.361 \\
\hline \multirow{2}{*}{ Mode of onset of pain } & Gradual & $83 \%(29)$ & $54 \%(19)$ & \multirow{2}{*}{0.010} \\
\hline & Injury & $17 \%(6)$ & $46 \%(116)$ & \\
\hline \multirow{2}{*}{ Pain distribution } & Unilateral & $20 \%(7)$ & $23 \%(8)$ & \multirow{2}{*}{1.000} \\
\hline & Bilateral & $80 \%(28)$ & $77 \%(27)$ & \\
\hline \multirow{2}{*}{ Pain distribution } & Back pain and leg pain equal & $89 \%(31)$ & $83 \%(29)$ & \multirow{2}{*}{0.853} \\
\hline & Leg pain worse than back pain & $11 \%(4)$ & $17 \%(6)$ & \\
\hline \multirow{4}{*}{ Disc herniation levels* } & $\mathrm{L} 2 / 3$ & $0 \%$ & $3 \%(1)$ & \multirow{4}{*}{ NA } \\
\hline & $\mathrm{L} 3 / 4$ & $6 \%(2)$ & $6 \%(2)$ & \\
\hline & $\mathrm{L} 4 / 5$ & $60 \%(21)$ & $69 \%(24)$ & \\
\hline & $\mathrm{L} 5 / \mathrm{S} 1$ & $71 \%(25)$ & $60 \%(21)$ & \\
\hline Numeric Rating Score & Mean \pm SD & $8.3 \pm 1.0$ & $7.7 \pm 0.9$ & 0.015 \\
\hline Oswestry Disability Index & Mean \pm SD & $29.8 \pm 4.6$ & $28.9 \pm 5.4$ & 0.432 \\
\hline
\end{tabular}

${ }^{*}$ more than one level of disc herniation was found in some patients

were composed of $5 \mathrm{~mL}$ of $0.5 \%$ lidocaine and one $\mathrm{mL}$ of non-particulate betamethasone. Intent-to-treat analyses was performed in Group I 13 times on 7 patients; for Group II, 5 times on 3 patients. Based on the number of treatments provided, lack of follow-up was found in 13 of 137 occasions in Group I (9\%) or 7 of 35 patients (20\%); whereas it was 5 of 146 occasions (3\%) in Group II with 3 of 35 patients $(9 \%)$ at least one time.

\section{Sensitivity Analysis}

A sensitivity analysis with changes in the numeric pain scale was performed utilizing the last follow-up score, best case scenario, and worst case scenario. There were no significant differences; therefore, the intention-to-treat analysis with last follow-up visit was used.

\section{Outcomes}

\section{Pain Relief}

Table 2 illustrates the NRS pain scores. Significant differences were observed between Group I and II at 6 month follow-up with Group II patients showing sig- nificantly higher reduction of pain scores $(P=0.001)$.

Figure 2 illustrates the percentage of patients experiencing significant pain relief, defined as $50 \%$ or greater.

\section{Functional Assessment}

Table 3 illustrates functional assessment scores. There were significant differences noted in the ODI scores at 6 months and 12 months with Group II patients illustrating superior results $(P=0.019$ and 0.045$)$.

Figure 3 illustrates results of significant improvement in functional status.

\section{Employment Characteristics}

Table 4 illustrates each group's employment characteristics. At baseline, there were 12 patients deemed employment eligible in Group I and 16 patients deemed eligible in Group II; each group's numbers remained steady at 12 months. Of these, Group I had 9 employed; Group II had 11 employed at baseline. Group II showed an improvement in employment status from 11 (69\%) to $14(88 \%)$. 
Table 2. Pain relief characteristics.

\begin{tabular}{|l|c|c|c||}
\hline \multirow{2}{*}{$\begin{array}{c}\text { Numeric Rating } \\
\text { Score }\end{array}$} & Group I (35) & Group II (35) & \multirow{2}{*}{ P value } \\
\cline { 2 - 3 } & Mean \pm SD & Mean \pm SD & \\
\hline Baseline & $8.3 \pm 1.0$ & $7.7 \pm 0.9$ & 0.015 \\
\hline 3 months & $3.9^{*} \# \pm 1.2$ & $3.5^{*} \pm 1.1$ & 0.096 \\
\hline 6 months & $4.3^{*} \pm 1.3$ & $3.4^{*} \pm 1.0$ & 0.001 \\
\hline 12 months & $3.9^{*} \# \pm 1.3$ & $3.3^{*} \pm 1.2$ & 0.090 \\
\hline
\end{tabular}

* indicates significant difference with baseline values $(P<0.001)$

\# indicates significant difference with 6 month values $(P<0.001)$
Table 3. Functional assessment evaluated by Oswestry Disability Index.

\begin{tabular}{|l|c|c|c|}
\hline $\begin{array}{c}\text { Oswestry } \\
\text { Disability Index }\end{array}$ & $\begin{array}{c}\text { Group I } \\
(\mathbf{3 5 )}\end{array}$ & $\begin{array}{c}\text { Group II } \\
(\mathbf{3 5})\end{array}$ & P value \\
\hline & Mean \pm SD & Mean \pm SD & \\
\hline Baseline & $29.8 \pm 4.6$ & $28.9 \pm 5.4$ & 0.432 \\
\hline 3 months & $15.4^{\star} \pm 5.2$ & $13.8^{\star} \pm 4.6$ & 0.174 \\
\hline 6 months & $16.2^{\star} \pm 5.4$ & $13.4^{\star} \pm 4.5$ & 0.019 \\
\hline 12 months & $15.2^{\star} \pm 5.5$ & $12.8^{\star} \pm 4.4$ & 0.045 \\
\hline
\end{tabular}

* indicates significant difference with baseline values $(P<0.001)$

\section{口 Group I 橉 Group II}

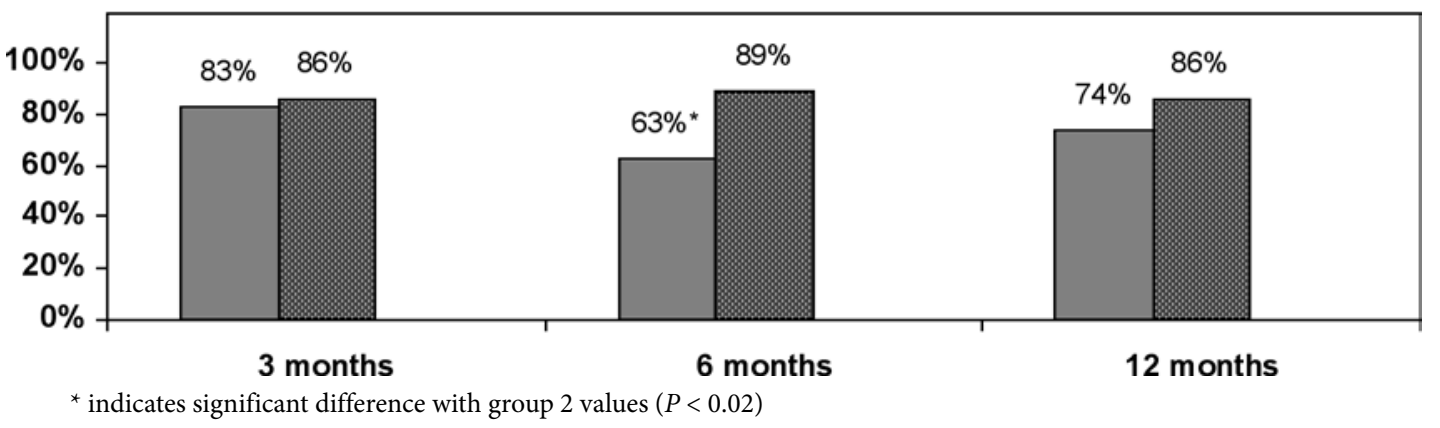

Fig. 2. Proportion of patients with significant pain relief $(\geq 50 \%)$.

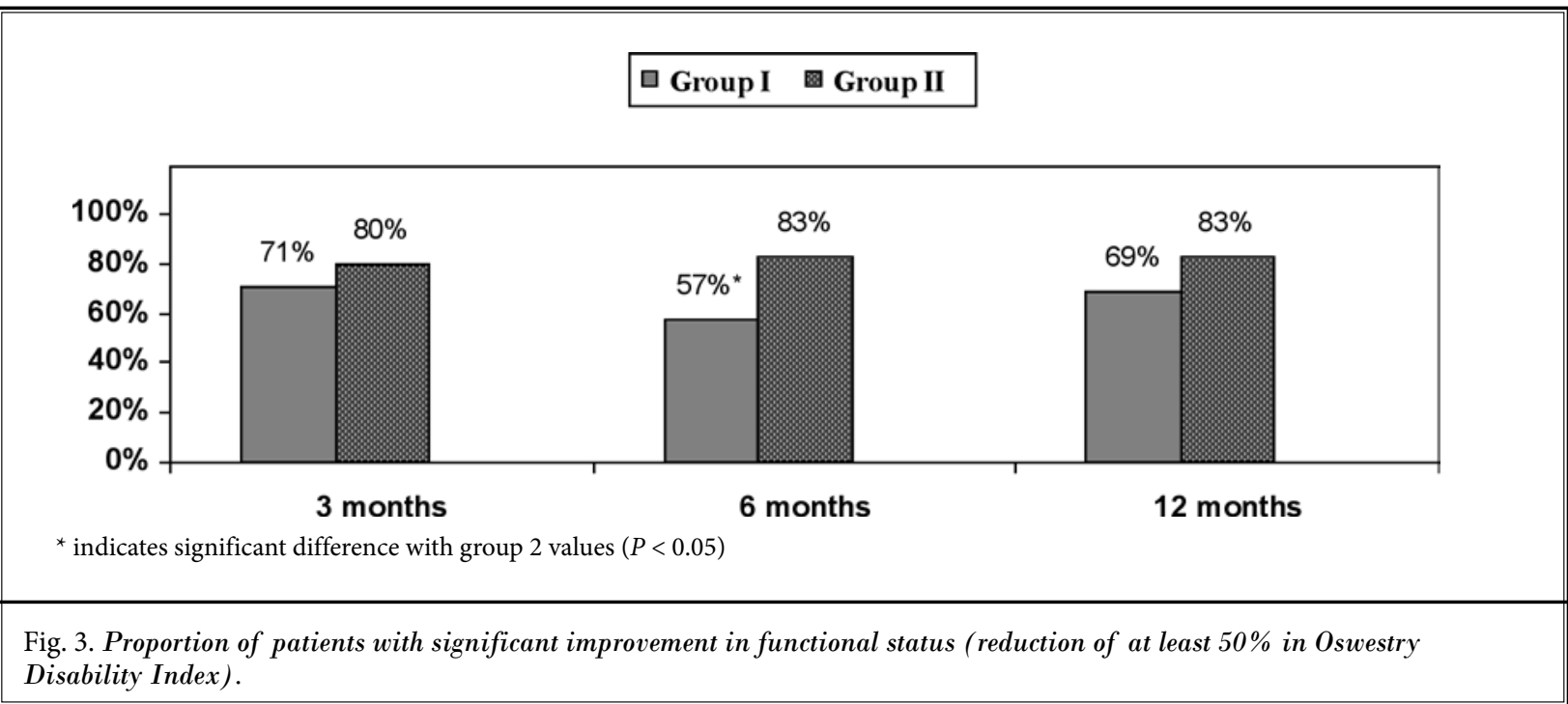


Table 4. Employment characteristics.

\begin{tabular}{|c|c|c|c|c|}
\hline \multirow{2}{*}{ Employment status } & \multicolumn{2}{|c|}{ Group I } & \multicolumn{2}{|c|}{ Group II } \\
\hline & Baseline & 12 months & Baseline & 12 months \\
\hline Employed part-time & 4 & 5 & 2 & 4 \\
\hline Employed full-time & 5 & 5 & 9 & 10 \\
\hline Unemployed (due to pain) & 0 & 1 & 3 & 1 \\
\hline Not working & 3 & 1 & 2 & 1 \\
\hline Eligible for employment & 12 & 12 & 16 & 16 \\
\hline Total Employed & 9 & 10 & 11 & 14 \\
\hline Housewife & 2 & 2 & 3 & 3 \\
\hline Disabled & 21 & 21 & 15 & 15 \\
\hline Retired & 0 & 0 & 1 & 1 \\
\hline Total Number of Patients & 35 & 35 & 35 & 35 \\
\hline
\end{tabular}

Table 5. Opioid intake (morphine equivalence mg) characteristics.

\begin{tabular}{|l|c|c|c|}
\hline \multirow{2}{*}{$\begin{array}{l}\text { Opioid Intake } \\
\text { Morphine Equivalence mg) }\end{array}$} & Group I (35) & Group II (35) & \multirow{2}{*}{ P value } \\
\cline { 2 - 4 } & Mean \pm SD & Mean \pm SD & 0.071 \\
\hline Baseline & $39 \pm 7.2$ & $57 \pm 58.5$ & 0.365 \\
\hline 3 months & $35^{*} \pm 7.5$ & $40^{*} \pm 36.1$ & 0.456 \\
\hline 6 months & $34^{*} \pm 9.3$ & $38^{*} \pm 34.5$ & 0.655 \\
\hline 12 months & $33^{*} \pm 10.9$ & $35^{*} \pm 35.6$ & \\
\hline
\end{tabular}

\# indicates significant difference with baseline values $(P<0.05)$

\section{Opioid Intake}

Table 5 illustrates opioid intake characteristics.

\section{Therapeutic Procedural Characteristics}

Table 6 illustrates therapeutic procedural characteristics. Lumbar interlaminar epidural injections were performed between L5 and S1 interspaces in $91 \%$ of patients, between L4 and L5 in 7\% of patients, and $2 \%$ of patients at other levels.

When a patient received consistent relief with both the first and second injections (lasting at least 3 weeks), the epidurals were deemed successful. All others were deemed failures. Those differences were successful group - Group I total injections per year $4.3 \pm 0.8$, total relief of $42.2 \pm 10.5$ weeks; Group II total injections per year $4.2 \pm 0.8$, total relief of $41.4 \pm 11.0$ weeks. In the failed group-Group I total injections per year $1.8 \pm 1.0$, total relief of $2.2 \pm 2.6$ weeks; Group II total injections per year $2.0 \pm 0.0$ without any significant relief.

Finally, there were a larger number of failed subjects in Group I compared to Group II with one in Group II and 6 in Group I.

\section{Changes in Weight}

There were significant differences in the weight at the beginning with Group I patients weighing more than the Group II patients $(P=0.011)$. Both groups showed some reduction with $54 \%$ in Group I and $57 \%$ in Group II losing weight with $20 \%$ in Group I and $9 \%$ in Group II with no change, whereas $26 \%$ in Group I and $34 \%$ in Group II gained weight (Table 7).

\section{Adverse Events}

Of the 283 lumbar interlaminar epidural procedures performed, there was one dural puncture, with no postoperative headache. There were no nerve root irritations. There were no other major adverse events.

\section{Discussion}

This preliminary report of the one year follow-up of a randomized, double-blind, controlled trial shows that patients can experience significant pain relief and functional status improvement with lumbar interlaminar epidural injections. One noteworthy result is that there were significant differences noted in patients re- 
Table 6. Therapeutic procedural characteristics with procedural frequency, average relief per procedure, and average total relief in weeks over a period of one year.

\begin{tabular}{|c|c|c|c|c|c|c|}
\hline & \multicolumn{2}{|c|}{ Successful Subjects } & \multicolumn{2}{|c|}{ Failed Subjects } & \multicolumn{2}{|c|}{ Combined (Overall) Results } \\
\hline & $\begin{array}{l}\text { Group I } \\
(29)\end{array}$ & $\begin{array}{c}\text { Group II } \\
(34)\end{array}$ & $\begin{array}{l}\text { Group I } \\
(6)\end{array}$ & $\begin{array}{l}\text { Group II } \\
\text { (1) }\end{array}$ & $\begin{array}{c}\text { Group I } \\
(35)\end{array}$ & $\begin{array}{l}\text { Group II } \\
(35)\end{array}$ \\
\hline 1st procedure relief & $6.0 \pm 4.3(29)$ & $\begin{array}{c}5.3 \pm 3.5 \\
(34)\end{array}$ & $\begin{array}{l}0.9 \pm 1.1 \\
(6)\end{array}$ & $\begin{array}{c}0 \\
(1)\end{array}$ & $\begin{array}{c}5.1 \pm 4.4 \\
(35)\end{array}$ & $\begin{array}{l}5.1 \pm 3.5 \\
(35)\end{array}$ \\
\hline 2nd procedure relief & $9.2 \pm 3.7(29)$ & $\begin{array}{l}8.2 \pm 3.8 \\
(34)\end{array}$ & $\begin{array}{c}1.7 \pm 2.9 \\
(3)\end{array}$ & $\begin{array}{c}0 \\
(1)\end{array}$ & $\begin{array}{l}8.5 \pm 4.3 \\
(32)\end{array}$ & $\begin{array}{c}8.0 \pm 3.9 \\
(35)\end{array}$ \\
\hline 3rd procedure relief & $11.7 \pm 4.0(29)$ & $\begin{array}{l}11.9 \pm 2.2 \\
(32)\end{array}$ & $\begin{array}{l}1.5 \pm 0.7 \\
\text { (2) }\end{array}$ & - & $\begin{array}{l}11.0 \pm 4.6 \\
\quad(31)\end{array}$ & $\begin{array}{l}11.9 \pm 2.2 \\
(32)\end{array}$ \\
\hline 4 th procedure relief & $11.4 \pm 3.8(23)$ & $\begin{array}{c}14.1 \pm 7.7 \\
(30)\end{array}$ & - & - & $\begin{array}{c}11.4 \pm 3.8 \\
(23)\end{array}$ & $\begin{array}{c}14.1 \pm 7.7 \\
(30)\end{array}$ \\
\hline 5th procedure relief & $12.6 \pm 1.1(16)$ & $\begin{array}{l}12.6 \pm 0.9 \\
\quad(14)\end{array}$ & - & - & $\begin{array}{l}12.6 \pm 1.1 \\
\quad(16)\end{array}$ & $\begin{array}{l}12.6 \pm 0.9 \\
(14)\end{array}$ \\
\hline $\begin{array}{l}\text { Number of procedures } \\
\text { per year }\end{array}$ & $4.3 \pm 0.8$ & $4.2 \pm 0.8$ & $1.8 \pm 1.0$ & 2.0 & $3.9 \pm 1.3$ & $4.2 \pm 0.9$ \\
\hline $\begin{array}{l}\text { Average relief per } \\
\text { procedure }\end{array}$ & $9.9 \pm 4.4$ & $10.0 \pm 5.5$ & $1.2 \pm 1.6$ & 0 & $9.2 \pm 4.8$ & $9.9 \pm 5.6$ \\
\hline $\begin{array}{l}\text { Average relief per pro- } \\
\text { cedure 3rd procedure } \\
\text { and after }\end{array}$ & $11.8 \pm 3.4$ & $12.9 \pm 5.1$ & $1.5 \pm 0.7$ & - & $11.5 \pm 3.8$ & $12.9 \pm 5.1$ \\
\hline $\begin{array}{l}\text { Total relief per year } \\
\text { (weeks) }\end{array}$ & $42.2 \pm 10.5$ & $41.4 \pm 11.0$ & $2.2 \pm 2.6$ & 0 & $35.3 \pm 18.1$ & $40.2 \pm 12.9$ \\
\hline
\end{tabular}

ceiving steroids. This trial of 70 patients demonstrates that $74 \%$ in Group I and $86 \%$ in Group II experienced significant pain relief (defined as $\geq 50 \%$ ) and $69 \%$ in Group I and $83 \%$ in Group II improved their functional status (defined as $\geq 50 \%$ reduction in Oswestry scores). These results were achieved with approximately 4 procedures per year. Average total relief per year over a 52 week period was approximately 42 weeks in successful groups, and 35 weeks in Group I and 40 weeks in Group Il overall.

Parr et al (11) in a systematic review concluded moderate evidence for short-term relief of pain of disc herniation or radiculitis utilizing blind interlaminar epidural steroid injections. Staal et al (12) concluded that there was insufficient evidence to support the use of injection therapy in subacute and chronic low back pain. Chou et al (13) concluded that there was fair evidence that epidural steroid injection is moderately effective for short-term (but not long-term) symptom relief.

The study presented here shows that long-term relief can be achieved by appropriate patient evaluation and judicious use of repeat injection therapy. An average relief of $11.8 \pm 3.4$ weeks without steroids, and 12.9
Table 7. Characteristics of changes in weight.

\begin{tabular}{|l|c|c|c|}
\hline \multirow{2}{*}{ Weight (lbs) } & Group I (35) & Group II (35) & \multirow{2}{*}{ P value } \\
\cline { 2 - 3 } & Mean \pm SD & Mean \pm SD & \\
\hline Weight at beginning & $211.7 \pm 54.9$ & $179.4 \pm 48.2$ & 0.011 \\
\hline Weight at one year & $208.3 \pm 56.6$ & $177.1 \pm 48.8$ & 0.016 \\
\hline Change & $-3.40 \pm 10.6$ & $-2.3 \pm 10.6$ & \multirow{2}{*}{0.671} \\
\hline Lost weight & $54 \%(19)$ & $57 \%(20)$ & \multirow{2}{*}{0.358} \\
\hline No change & $20 \%(7)$ & $9 \%(3)$ & \\
\hline Gained weight & $26 \%(9)$ & $34 \%(12)$ & \\
\hline
\end{tabular}

\pm 5.1 weeks with steroids is attainable after 2 injections in the therapeutic phase.

One interesting aspect of the present study is the insight it provides into successful and failed groups based on the first 2 procedures. While average pain relief was higher in the patients considered as the successful group, the steroid group showed significantly better pain relief and improvement in function at 6 months in Group II with steroids.

An important advantage of the present study is its relevancy for interventional pain management settings. Also, this study is the first in the United States conduct- 
ed with fluoroscopic visualization in a private practice setting. The present study's results can be applied to individual patients or groups that differ from those controlled in placebo trials. Explanatory trials that measure efficacy are inferior to pragmatic or practical clinical trials (with an active control) that measure effectiveness (25-27,30,31,70-74).

Criticism can be directed at our study, and some might consider it deficient, because it lacks a placebo group, that it is a preliminary analysis, and various baseline variables.

Despite past misinterpretations to the contrary, placebo-controlled neural blockade is not realistic $(51,75)$. Some have mistakenly reported that any local anesthetic injection with similar results as steroids should be considered a placebo. However, these interpretations are inaccurate. In a related matter, the difference between injections of sodium chloride solution and dextrose has been shown (76). Experiments and clinical studies have investigated the electrophysiological effects of $0.9 \%$ sodium chloride and dextrose $5 \%$ in water solution. These experiments and studies have added new knowledge as well as new controversy to multiple aspects of neural stimulation used in regional anesthesia. The potential inaccuracy created by $0.9 \%$ sodium chloride solution versus $5 \%$ dextrose has been described $(76,77)$. Further, the evidence also has shown differing effects of sodium chloride solution when injected into either the disc, the facet joint, or paraspinal muscles $(78,79)$. In addition, the literature is replete with studies illustrating the effectiveness of sodium chloride solution when injected into the epidural space (80-82).

This preliminary analysis is justifiable due to the lack of reports in the past with lumbar interlaminar epidural injections performed utilizing fluoroscopy.

Other limitations include significant differences in the inclusion of the proportion of patients, with females higher in Group I than Group II, higher mean weight in Group I compared to Group II, and mode of onset with $83 \%$ of patients with gradual onset in Group $\mathrm{I}$, and numeric pain rating scores of 8.3 in Group I versus 7.7 in Group II. However, at present, it is not known if any of these factors would have influenced the results. Gender and weight do not appear to be relevant to the response. However, patients with gradual onset may respond in an inferior manner compared to the patients with onset following an injury. Finally, the higher initial numeric pain rating scores in Group I may have influenced significant decreases of pain scores at 6 months in Group II. These deficiencies may be addressed in the final results of this study with long-term follow-up or in larger studies.

While the mechanism of action of steroids and local anesthetic has been described (34-48), evidence has emerged showing that local anesthetics may be just as effective as steroids in managing low back pain without disc herniation as well as pain of facet joint origin (4960 ). It has been reported that multiple pathophysiologic mechanisms involved in chronic pain include noxious peripheral stimulation; excess nociception resulting in the sensitization of the pain pathways at several neuronal levels $(83,84)$; and excess release of neurotransmitters causing complex central responses including hyperalgesia or wind-up (41). These result in an increase in nociceptive sensitization of the nervous system $(85,86)$ and phenotype changes which are also considered to be part of the neuronal plasticity $(85,86)$. Therefore, the evidence shows patients can receive long-term relief from radicular pain with the use of either local anesthetics or steroids, even though steroids appear to be superior.

\section{Conclusion}

Assessment of the preliminary results of this randomized, double-blind, controlled trial of lumbar interlaminar epidural injections in chronic function-limiting low back pain and lower extremity pain with disc herniation or radiculitis demonstrated effectiveness in 74\% of patients with local anesthetic only and in $86 \%$ of patients with local anesthetic and steroids with significant functional status improvement requiring approximately 4 procedures per year with approximately 42 weeks of relief during a 52-week period in appropriately selected patients.

\section{Acknowledgments}

The authors wish to thank Sekar Edem for assistance in the search of the literature, Tom Prigge for manuscript review, and Tonie M. Hatton and Diane E. Neihoff, transcriptionists, for their assistance in preparation of this manuscript. We would like to thank the editorial board of Pain Physician for review and criticism in improving the manuscript. 


\section{References}

1. Mixter WJ, Barr JS. Rupture of the intervertebral disc with involvement of the spinal canal. N Eng J Med 1934; 211:210-215.

2. Manchikanti L, Boswell MV, Singh V, Benyamin RM, Fellows B, Abdi S, Buenaventura RM, Conn A, Datta S, Derby R, Falco FJE, Erhart S, Diwan S, Hayek SM, Helm S, Parr AT, Schultz DM, Smith HS, Wolfer LR, Hirsch JA. Comprehensive evidence-based guidelines for interventional techniques in the management of chronic spinal pain. Pain Physician 2009; 12:699-802.

3. Manchikanti L. Singh V, Datta S, Cohen SP, Hirsch JA. Comprehensive review of epidemiology, scope, and impact of spinal pain. Pain Physician 2009; 12: E35-E70.

4. Konstantinou K, Dunn KM. Sciatica: Review of epidemiological studies and prevalence estimates. Spine (Phila Pa 1976) 2008; 33:2464-2472.

5. Mixter WJ, Ayers JB. Herniation or rupture of the intervertebral disc into the spinal canal. N Engl J Med 1935; 213:385-395.

6. Wheeler AH, Murrey DB. Chronic lumbar spine and radicular pain: Pathophysiology and treatment. Curr Pain Headache Rep 2002; 6:97-105.

7. Hadjipavlou AG, Tzermiadianos MN, Bogduk N, Zindrick MR. The pathophysiology of disc degeneration: A critical review. J Bone Joint Surg Br 2008; 90:1261-1270.

8. Genevay S, Finckh A, Payer M, Mezin F, Tessitore E, Gabay C, Guerne PA. Elevated levels of tumor necrosis factoralpha in periradicular fat tissue in patients with radiculopathy from herniated disc. Spine (Phila Pa 1976) 2008; 33:2041-2046.

9. Sugiura $A$, Ohtori $S$, Yamashita $M$, Inoue G, Yamauchi K, Koshi T, Suzuki M, Norimoto M, Orita S, Eguchi Y, Takahashi Y, Watanabe TS, Ochiai N, Takaso $M$, Takahashi K. Existence of nerve growth factor receptors, tyrosine kinase $a$ and $p 75$ neurotrophin receptors in intervertebral discs and on dorsal root ganglion neurons innervating intervertebral discs in rats. Spine (Phila Pa 1976) 2008; 33:2047-2051.

10. McCarron RF, Wimpee MW, Hudkins PG, Laros GS. The inflammatory effect of nucleus pulposus: A possible element in the pathogenesis of low-back pain. Spine (Phila Pa 1976) 1987; 12:760-
764.

11. Parr AT, Diwan S, Abdi S. Lumbar interlaminar epidural injections in managing chronic low back and lower extremity pain: A systematic review. Pain Physician 2009; 12:163-188.

12. Staal JB, de Bie R, de Vet HC, Hildebrandt J, Nelemans P. Injection therapy for subacute and chronic low-back pain: An updated Cochrane review. Spine (Phila Pa 1976) 2009; 34:49-59.

13. Chou R, Atlas SJ, Stanos SP, Rosenquist RW. Nonsurgical interventional therapies for low back pain: A review of the evidence for an American Pain Society clinical practice guideline. Spine (Phila Pa 1976) 2009; 34:1078-1093.

14. Manchikanti L, Singh V, Pampati V, Smith HS, Hirsch JA. Analysis of growth of interventional techniques in managing chronic pain in Medicare population: A 10-year evaluation from 1997 to 2006. Pain Physician 2009; 12:9-34.

15. Manchikanti L, Pampati V, Boswell MV, Smith HS, Hirsch JA. Analysis of the growth of epidural injections and costs in the Medicare population: A comparative evaluation of 1997, 2002, and 2006 data. Pain Physician 2010; 13:199-212.

16. Manchikanti L, Pampati V, Singh V, Boswell MV, Smith HS, Hirsch JA. Explosive growth of facet joint interventions in the Medicare population in the United States: A comparative evaluation of 1997, 2002, and 2006 data. BMC Health Serv Res 2010; 10:84.

17. Manchikanti L, Singh V, Derby R, Schultz DM, Benyamin RM, Prager JP, Hirsch JA. Reassessment of evidence synthesis of occupational medicine practice guidelines for interventional pain management. Pain Physician 2008; 11:393482.

18. Armon C, Argoff CE, Samuels J, Backonja MM; Therapeutics and Technology Assessment Subcommittee of the American Academy of Neurology. Assessment: Use of epidural steroid injections to treat radicular lumbosacral pain: Report of the Therapeutics and Technology Assessment Subcommittee of the American Academy of Neurology. Neurology 2007; 68:723-729.

19. Conn A, Buenaventura R, Datta $S$, Abdi $S$, Diwan S. Systematic review of caudal epidural injections in the management of chronic low back pain. Pain Physician 2009; 12:109-135.

20. Benyamin RM, Singh V, Parr AT, Conn
A, Diwan S, Abdi S. Systematic review of the effectiveness of cervical epidurals in the management of chronic neck pain. Pain Physician 2009; 12:137-157.

21. Buenaventura RM, Datta $S$, Abdi $S$, Smith HS. Systematic review of therapeutic lumbar transforaminal epidural steroid injections. Pain Physician 2009; 12:233-251.

22. Manchikanti L, Boswell MV, Datta S, Fellows $B$, Abdi S, Singh V, Benyamin RM, Falco FJE, Helm S, Hayek S, Smith HS. Comprehensive review of therapeutic interventions in managing chronic spinal pain. Pain Physician 2009: 12:E123E198.

23. Manchikanti L, Singh V, Derby R, Helm $S$, Trescot AM, Staats PS, Prager JP, Hirsch JA. Review of occupational medicine practice guidelines for interventional pain management and potential implications. Pain Physician 2008; 11:271-289.

24. Manchikanti L, Singh V, Helm S, Trescot AM, Hirsch JA. A critical appraisal of 2007 American College of Occupational and Environmental Medicine (ACOEM) practice guidelines for interventional pain management: An independent review utilizing AGREE, AMA, IOM, and other criteria. Pain Physician 2008; 11:291-310.

25. Manchikanti L. Evidence-based medicine, systematic reviews, and guidelines in interventional pain management: Part 1: Introduction and general considerations. Pain Physician 2008; 11:161-186.

26. Manchikanti L, Hirsch JA, Smith HS. Evidence-based medicine, systematic reviews, and guidelines in interventional pain management: Part 2: Randomized controlled trials. Pain Physician 2008; 11:717-773.

27. Manchikanti L, Benyamin RM, Helm S, Hirsch JA. Evidence-based medicine, systematic reviews, and guidelines in interventional pain management: Part 3: Systematic reviews and meta-analysis of randomized trials. Pain Physician 2009; 12:35-72.

28. Manchikanti L, Singh V, Smith HS, Hirsch JA. Evidence-based medicine, systematic reviews, and guidelines in interventional pain management: Part 4: Observational studies. Pain Physician 2009; 12:73-108.

29. Manchikanti L, Derby $R$, Wolfer LR, Singh V, Datta S, Hirsch JA. Evidence- 
based medicine, systematic reviews, and guidelines in interventional pain management: Part 5: Diagnostic accuracy studies. Pain Physician 2009; 12:517-540.

30. Manchikanti L, Falco FJE, Boswell MV, Hirsch JA. Facts, fallacies, and politics of comparative effectiveness research: Part I. Basic considerations. Pain Physician 2010; 13:E23-E54.

31. Manchikanti L, Falco FJE, Boswell MV Hirsch JA. Facts, fallacies, and politics of comparative effectiveness research: Part 2. Implications for interventional pain management. Pain Physician 2010; 13:E55-E79.

32. Manchikanti L, Datta S, Derby R, Wolfer LR, Benyamin RM, Hirsch JA. A critical review of the American Pain Society clinical practice guidelines for interventional techniques: Part 1. Diagnostic interventions. Pain Physician 2010; 13: E141-E174.

33. Manchikanti L, Datta S, Gupta S, Munglani $R$, Bryce DA, Ward SP, Benyamin RM, Sharma M, Helm II $S$, Fellows $B$, Hirsch JA. A critical review of the American Pain Society clinical practice guidelines for interventional techniques: Part 2. Therapeutic interventions. Pain Physician 2010;13:E215-E265.

34. Manchikanti L. Role of neuraxial steroids in interventional pain management. Pain Physician 2002; 5:182-199.

35. Byrod G, Otani K, Brisby H, Rydevik B, Olmarker K. Methylprednisolone reduces the early vascular permeability increase in spinal nerve roots induced by epidural nucleus pulposus application. J Orthop Res 2000; 18:983-987.

36. Lundin A, Magnuson A, Axelsson K, Nilsson O, Samuelsson L. Corticosteroids preoperatively diminishes damage to the C-fibers in microscopic lumbar disc surgery. Spine (Phila Pa 1976) 2005; 30:2362-2367.

37. Hua SY, Chen YZ. Membrane receptormediated electrophysiological effects of glucocorticoid on mammalian neurons. Endocrinology 1989; 124:687691.

38. Hayashi N, Weinstein JN, Meller ST, Lee HM, Spratt KF, Gebhart GF. The effect of epidural injection of betamethasone or bupivacaine in a rat model of lumbar radiculopathy. Spine (Phila Pa 1976) 1998; 23:877-885.

39. Lee HM, Weinstein JN, Meller ST, Hayashi N, Spratt KF, Gebhart GF. The role of steroids and their effects on phospholipase A2: An animal model of radiculopathy. Spine (Phila Pa 1976) 1998; 23:1191-1196.

40. Minamide A, Tamaki T, Hashizume H, Yoshida M, Kawakami M, Hayashi N. Effects of steroids and lipopolysaccharide on spontaneous resorption of herniated intervertebral discs: An experimental study in the rabbit. Spine (Phila Pa 1976) 1998; 23:870-876.

41. Pasqualucci $A$, Varrassi $G$, Braschi $A$ Peduto VA, Brunelli $A$, Marinangeli $F$ Gori F, Colò F, Paladín A, Mojoli F. Epidural local anesthetic plus corticosteroid for the treatment of cervical brachial radicular pain: Single injection verus continuous infusion. Clin J Pain 2007; 23:551-557.

42. Tachihara H, Sekiguchi M, Kikuchi S, Konno S. Do corticosteroids produce additional benefit in nerve root infiltration for lumbar disc herniation. Spine (Phila Pa 1976) 2008; 33:743-747.

43. Mao J, Chen LL. Systemic lidocaine for neuropathic pain relief. Pain 2000 87:7-17.

44. Pasqualucci A. Experimental and clinical studies about the preemptive analgesia with local anesthetics. Possible reasons of the failure. Minerva Anestesiol 1998; 64:445-457.

45. Arner S, Lindblom U, Meyerson BA, Molander $C$. Prolonged relief of neuralgia after regional anesthetic block. A call for further experimental and systematic clinical studies. Pain 1990; 43:287297.

46. Lavoie PA, Khazen T, Filion PR. Mechanisms of the inhibition of fast axonal transport by local anesthetics. Neuropharmacology 1989; 28:175-181.

47. Bisby MA. Inhibition of axonal transport in nerves chronically treated with local anesthetics. Exp Neurol 1975; 47:481-489.

48. Sato C, Sakai A, Ikeda $Y$, Suzuki $H$, Sakamoto $A$. The prolonged analgesic effect of epidural ropivacaine in a rat model of neuropathic pain. Anesth Analg 2008; 106:313-320.

49. Riew KD, Park JB, Cho YS, Gilula L, Patel $A$, Lente LG, Bridwell KH. Nerve root blocks in the treatment of lumbar radicular pain. A minimum five-year follow-up. J Bone Joint Surg Am 2006; 88:1722-1725.

50. Manchikanti L, Singh V, Falco FJ, Cash KA, Pampati V. Lumbar facet joint nerve blocks in managing chronic facet joint pain: One-year follow-up of a random- ized, double-blind controlled trial; Clinical Trial NCT00355914. Pain Physician 2008; 11:121-132.

51. Manchikanti L, Singh V, Falco FJ, Cash KA, Fellows B. Cervical medial branch blocks for chronic cervical facet joint pain: A randomized double-blind, controlled trial with one-year follow-up. Spine (Phila Pa 1976) 2008; 33:18131820.

52. Manchikanti L, Singh V, Falco FJE, Cash KA, Pampati V. Evaluation of lumbar facet joint nerve blocks in managing chronic low back pain: A randomized, double-blind, controlled trial with a 2-year follow-up. Int J Med Sci 2010; 7:124-135.

53. Manchikanti L, Singh V, Falco FJE, Cash KA, Pampati V. Effectiveness of thoracic medial branch blocks in managing chronic pain: A preliminary report of a randomized, double-blind controlled trial; Clinical trial NCT00355706. Pain Physician 2008; 11:491-504.

54. Manchikanti L, Cash KA, McManus CD, Pampati V, Smith HS. Preliminary results of randomized, equivalence trial of fluoroscopic caudal epidural injections in managing chronic low back pain: Part 1. Discogenic pain without disc herniation or radiculitis. Pain Physician 2008; 11:785-800.

55. Manchikanti L, Singh V, Cash KA, Pampati V, Damron KS, Boswell MV. Preliminary results of randomized, equivalence trial of fluoroscopic caudal epidural injections in managing chronic low back pain: Part 2. Disc herniation and radiculitis. Pain Physician 2008; 11:801-815.

56. Manchikanti L, Singh V, Cash KA, Pampati V, Datta S. Preliminary results of randomized, equivalence trial of fluoroscopic caudal epidural injections in managing chronic low back pain: Part 3. Post surgery syndrome. Pain Physician 2008; 11:817-831.

57. Manchikanti L, Cash KA, McManus CD, Pampati V, Abdi S. Preliminary results of randomized, equivalence trial of fluoroscopic caudal epidural injections in managing chronic low back pain: Part 4. Spinal stenosis. Pain Physician 2008; 11:833-848.

58. Manchikanti L, Cash KA, Pampati V, Wargo BW, Malla Y. Cervical epidural injections in chronic discogenic neck pain without disc herniation or radiculitis: Preliminary results of a randomized, double-blind, controlled trial. 
Pain Physician 2010; 13:E265-E278.

59. Manchikanti L, Cash KA, Pampati V, Wargo BW, Malla Y. The effectiveness of fluoroscopic cervical interlaminar epidural injections in managing chronic cervical disc herniation and radiculitis: Preliminary results of a randomized, double-blind, controlled trial. Pain Physician 2010; 13:223-236.

60. Manchikanti L, Cash KA, McManus CD, Pampati V, Benyamin RM. Preliminary results of a randomized, double-blind, controlled trial of fluoroscopic lumbar interlaminar epidural injections in managing chronic lumbar discogenic pain without disc herniation or radiculitis. Pain Physician 2010; in press.

61. Moher D, Schulz KF, Altman D, for the CONSORT Group. The CONSORT statement: Revised recommendations for improving the quality of reports of parallel-group randomized trials. JAMA 2001; 285:1987-1991.

62. Altman DG, Schulz KF, Moher D, Egger M, Davidoff F, Elbourne D, Gøtzsche PC, Lang T; CONSORT GROUP (Consolidated Standards of Reporting Trials). The revised CONSORT statement for reporting randomized trials: Explanation and elaboration. Ann Intern Med 2001; 134:663-694.

63. Carragee EJ. The rise and fall of the "minimum clinically important difference". Spine J 2010; 10:283-284.

64. Fairbank JCT, Pynsent PB. The Oswestry disability index. Spine (Phila Pa 1976) 2000; 25:2940-2953.

65. Pereira J, Lawlor P, Vigano A, Dorgan $M$, Bruera E. Equianalgesic dose ratios for opioids. A critical review and proposals for long-term dosing. J Pain Symptom Manage 2001; 22:672-687. Narcotic analgesic converter, GlobalRPh Inc. www.globalrph.com/narcotic.cgi

66. Browner WS, Newman TB, Cummings SR, Hulley SB. Estimating sample size and power. In: Hulley SB, Cummings SR, Browner WS, Grady D, Hearst N, Newman TB (eds). Designing Clinical Research: An Epidemiologic Approach, 2nd ed. Lippincott, Williams \& Wilkins, Philadelphia, 2001, pp 65-84.

67. Koes BW, Scholten RJ, Mens JMA, Bouter LM. Epidural steroid injections for low back pain and sciatica. An updated systematic review of randomized clinical trials. Pain Digest 1999; 9:241-247.

68. Manchikanti L, Cash KA, McManus CD, Pampati V, Singh V, Benyamin RM. The preliminary results of a comparative effectiveness evaluation of adhesiolysis and caudal epidural injections in managing chronic low back pain secondary to spinal stenosis: A randomized, equivalence controlled trial. Pain Physician 2009; 12:E341-E354.

69. Manchikanti L, Singh V, Cash KA, Pampati V, Datta S. A comparative effectiveness evaluation of percutaneous adhesiolysis and epidural steroid injections in managing lumbar post surgery syndrome: A randomized, equivalence controlled trial. Pain Physician 2009; 12:E355-E368.

70. Hotopf $M$. The pragmatic randomized controlled trial. Adv Psychiatr Treat 2002; 8:326-333.

71. Hotopf M, Churchill R, Lewis G. Pragmatic randomized controlled trials in psychiatry. $\mathrm{Br} /$ Psychiatry 1999; 175:217-223.

72. Tunis SR, Stryer DB, Clancy CM. Practical clinical trials. Increasing the value of clinical research for decision making in clinical and health policy. JAMA 2003; 290:1624-1632.

73. Roland $M$, Torgerson DJ. What are pragmatic trials? BMJ 1998; 316:285.

74. International Conference on Harmonisation of Technical Requirements for Registration of Pharmaceuticals for Human Use. ICH Harmonised Tripartite Guideline. Choice of Control Group and Related Issues in Clinical Trials E10. July 20, 2000.

75. Manchikanti L, Singh V, Falco FJE. In response to Smuck $M$, Levin JH. RE: Manchikanti L, Singh V, Falco FJE, Cash KA, Fellows B. Cervical medial branch blocks for chronic cervical facet joint pain: A randomized double-blind, controlled trial with one-year follow-up. Spine (Phila Pa 1976) 2009; 34:11161117.

76. Pham Dang C, Lelong A, Guilley J, Nguyen JM, Volteau C, Venet G, Perrier C, Lejus C, Blanloeil Y. Effect on neurostimulation of injectates used for perineural space expansion before placement of a stimulating catheter: Normal saline versus dextrose $5 \%$ in water. Reg Anesth Pain Med 2009; 34:398-403.

77. Tsui BC, Kropelin B, Ganapathy S, Finucane B. Dextrose $5 \%$ in water: Fluid medium maintaining electrical stimulation of peripheral nerve during stimulating catheter placement. Acta Anaesthesiol Scand 2005; 49:1562-1565.

78. Indahl A, Kaigle AM, Reikeräs O, Holm $\mathrm{SH}$. Interaction between the porcine lumbar intervertebral disc, zygapophysial joints, and paraspinal muscles. Spine (Phila Pa 1976) 1997; 22:28342840.

79. Indahl A, Kaigle A, Reikerås O, Holm $S$. Electromyographic response of the porcine multifidus musculature after nerve stimulation. Spine (Phila $\mathrm{Pa}$ 1976) 1995; 20:2652-2658.

80. Bhatia MT, Parikh LCJ. Epidural saline therapy in lumbo-sciatic syndrome. J Indian Med Assoc 1966; 47:537-542.

81. Gupta AK, Mital VK, Azmi RU. Observations of the management of lumbosciatic syndromes (sciatica) by epidural saline. J Indian Med Assoc 1970; 54:194-196.

82. Wittenberg RH, Greskötter KR, Steffen $R$, Schoenfeld BL. Is epidural injection treatment with hypertonic saline solution in intervertebral disk displacement useful? (The effect of $\mathrm{NaCl}$ solution on intervertebral disk tissue). $Z$ Orthop Ihre Grenzgeb 1990; 128:223226.

83. Katz WA, Rothenberg R. The nature of pain: Pathophysiology. I Clin Rheumatol 2005; 11:S11-S15.

84. Melzack R, Coderre TJ, Katz J, Vaccarino AL. Central neuroplasticity and pathological pain. Ann N Y Acad Sci 2001; 933:157-174.

85. Kawakami M, Weinstein JN, Chatani K, Spratt KF, Meller ST, Gebhart GF. Experimental lumbar radiculopathy. Behavioral and histologic changes in a model of radicular pain after spinal nerve root irritation with chromic gut ligatures in the rat. Spine (Phila Pa 1976) 1994; 19:1795-1802.

86. Decosterd I, Woolf CJ. Spared nerve injury: An animal model of persistent peripheral neuropathic pain. Pain 2000; 87:149-158. 
